\title{
Shoot Formation on Floral Organs of Japanese Iris in Vitro
}

\author{
Koshiro Kawase, Hiroshi Mizutani* , Mari Yoshioka and Sonoko Fukuda \\ Experimental Farm. Kyoto University, Takatsuki, Osaka 569
}

\begin{abstract}
Summary
For the purpose of achieving micropropagation in Japanese iris (Iris ensata Thunb.), various explants, namely pistils, perianths, stamens, anthers, filaments, perianth-ovary junctions, ovaries and pedicels, were cultured in vitro on MS media with or without BA and NAA.

Shoot formation was observed from explants of perianth-ovary junctions and upper portions of ovaries on media containing BA and NAA. Explants of lower portions of ovaries formed shoots only on the medium containing $5 \mathrm{mg} \cdot$ liter $^{-1} \mathrm{BA}$ and $5 \mathrm{mg} \cdot \mathrm{liter}^{-1}$ NAA. A higher frequency of shoot formation was observed in explants of perianth-ovary junctions than those of ovaries.

No roots were differentiated from any explants except those from ovaries and pedicels. Most explants of lower portions of ovaries showed root formation on media with BA and NAA, but those from upper portions showed root formation only on a medium with 1 $\mathrm{mg} \cdot$ liter $^{-1}$ each of BA and NAA. Those of pedicels showed root formation with a frequency of 33 percent on a medium without plant growth regulators.

Callus formation occurred from ovary and stamen explants. The frequency of callus formation from ovary explants was 100 percent on media with BA and NAA. Stamen explants showed 11 percent callus formation on a $5 \mathrm{mg} \cdot \operatorname{liter}^{-1} \mathrm{BA}$ plus $5 \mathrm{mg} \cdot \operatorname{liter}^{-1} \mathrm{NAA}$ medium.
\end{abstract}

\section{Introduction}

Japanese iris (Iris ensata Thunb. ; I. kaempferi Seib., used in Europe, is botanically incorrect) (Kohlein, 1987), a perennial plant having rhizomatous roots, is excellent for wet borders. Traditional propagation by the division of rhizomes, wherein only one or two offsets are obtained per rhizome per year, is too slow to produce sufficient quantities of plants, particularly new cultivars, for market demand (Ichihashi and Kato, 1986; Meyer et al., 1975; Yabuya et al., 1991), so that a more efficient method is required.

Plant tissue culture in vitro was previously considered as one such method, however, it was not possible to make explants from rhizomes and

Received for publication 7 March 1994.

A part of this study was presented at the spring meeting of the Japanese Society for Horticultural Science, Tokyo, 1991.

*Present address : Nagahama, Agri. High School, Nagaha ma, Shiga 526 bulbs or corms free from contamination (Hussey, 1975; Ichihashi and Kato, 1986; Kawase et al., unpublished manuscript).

Several workers have reported induction of shoots from explants of floral organs, i. e., petals of Hemerocallis (Heuser and Apps, 1976), ovaries and inflorescences of some members of Liliaceae, Iridaceae and Amaryllidaceae (Hussey, 1975), ovaries and sepals of Omithogalum (Hussey, 1976), petals, floral disks, filaments and pistils of flowering kale (Brassica oleracea var. acephala DC.), Italian broccoli ( $B$. oleracea var. italica Plenck) and orychophragmus (Orychophragmus violaceus O. E. Schulz.) (lizuka et al., 1978) and filaments of Lilium regale (Montezuma-de-Carvalho and Guimaraes, 1974). For rhizomatous irises, shoot regeneration has been achieved in explants from peduncles or flower-stalks (Meyer et al., 1975; Meyer, 1984) and ovaries (Ichihashi and Kato, 1986). These explants were obtained almost free from contamination.

Consequently, we tried to culture explants from 
various floral organs on MS medium in order to identify plant tissues showing high potential for shoot regeneration.

\section{Materials and Methods}

Five cultivars of Iris ensata Thunb. ('Ageha', 'Fujibakama', 'Hananomiyako', 'Musashino' and 'Wakamurasaki') were used as experimental materials. Flower buds were taken between the stage when perianths were still enclosed with bracts and that when they had just emerged from the bracts. After excision, they were quickly dipped in $70 \%$ ethanol, surface-sterilized by $0.4 \sim 0.7 \%$ active chlorine solution ( $5 \%$ sodium hypochlorite solution) mixed with a few drops of polyoxyethylene sorbitan (Tween 20) for $15 \mathrm{~min}$, and then rinsed with sterile water.

Explants excised for tissue culture were as follows; perianth-ovary junctions, filaments and ovaries from 'Fujibakama', and pistils, perianths, stamens, anthers, and pedicels from 'Ageha', 'Hananomiyako', 'Musashino' and 'Wakamurasaki' (Fig. 1). Perianth-ovary junctions were divided by vertical cuts into three sections, each of which had one filament, and were approximately $3 \mathrm{~mm}$ in width and $4 \mathrm{~mm}$ in length. Ovaries were cut horizontally into upper and lower portions, each of which was further cut vertically into two sections (Fig. 2). Each section was approximately $4 \mathrm{~mm}$ in width and $4 \mathrm{~mm}$ in height.

Explants from all floral organs except ovaries were placed with lower surface down, while those of ovaries were placed with vertical surface down onto a medium consisted of MS salts plus 100 $\mathrm{mg} \cdot$ liter $^{-1}$ myo-inositol, $0.1 \mathrm{mg} \cdot$ liter $^{-1}$ thiamine$\mathrm{HCl}, 30 \mathrm{~g} \cdot$ liter $^{-1}$ sucrose and $10 \mathrm{~g} \cdot$ liter $^{-1}$ agar. A

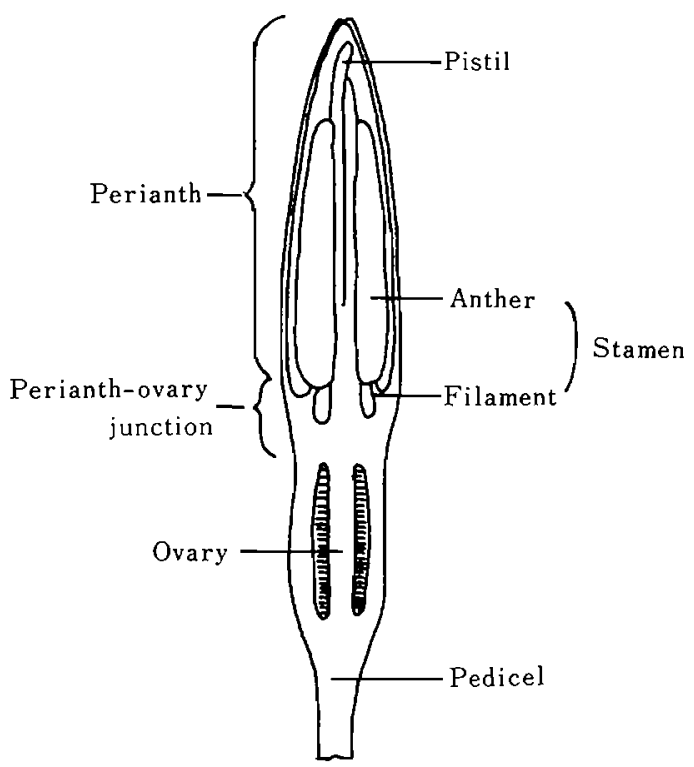

Fig. 1. Schematic diagram of Japanese iris flower bud (side view).

test tube $(1.8 \times 11.0 \mathrm{~cm})$ containing $5 \mathrm{ml}$ of the medium was used for the culture of explants.

Four combinations of the plant growth regulators BA and NAA (BA-NAA; 0-0, 1-1, 5-1 and 5-5 $\mathrm{mg} \cdot$ liter $^{-1}$ ), were tested in the medium. The $\mathrm{pH}$ was adjusted to 5.8 prior to autoclaving for 15 min at $120^{\circ} \mathrm{C}$ and $1.2 \mathrm{~kg} \cdot \mathrm{cm}^{-1}$.

All test tubes were placed in a controlled environment room at $25{ }^{\circ} \mathrm{C}$. Light $(2500 \sim 3000 \mathrm{~lx})$ was supplied by white fluorescent tubes for $12 \mathrm{hr}$ per day.
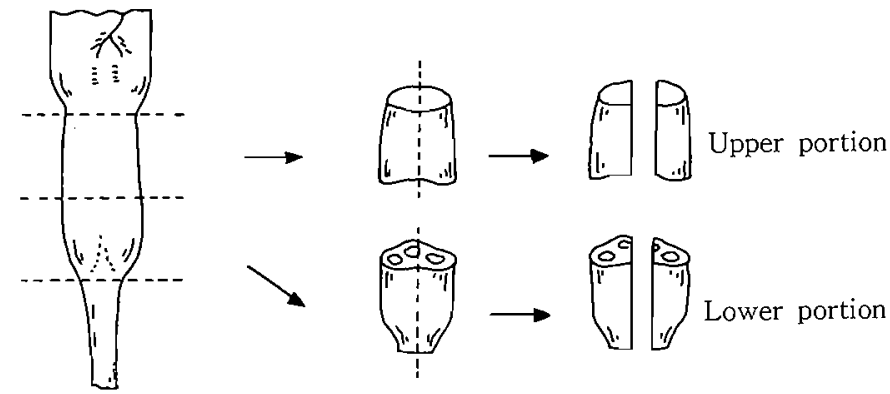

Fig. 2. Lateral view of ovary and preparation of ovary explants. Broken lines represent cutting. 


\section{Results}

\section{Shoot formation}

On media with BA and NAA, shoots appeared only from explants of perianth-ovary junctions and ovaries of 'Fujibakama'. Other organs, including filaments of 'Fujibakama' and pistils, perianths, stamens, anthers, and pedicels of 'Ageha', 'Hananomiyako', 'Musashino' and 'Wakamurasaki', never formed shoots on any medium, even those containing BA and NAA.

Perianth-ovary junctions cultured on MS media with BA and NAA showed a very high percentage of shoot formation (Tables 1 and 2). Several shoots were produced by each explant (Figs. 3 and 4). The appearance of shoots was observed at the regions adjacent to a filament.

For the purpose of clarifying the influence of the presence of a filament on shoot formation of perianth-ovary junctions, perianth-ovary junctions with and without a filament were used (Table 2). Both produced shoots at a high frequency with no difference in the ability of shoot formation (Figs. 3 and 4). Explants of filaments alone produced no shoots.

In the case of ovaries, no shoots were induced from any explants on a medium without $B A$ and NAA, but shoot formation of upper portions was

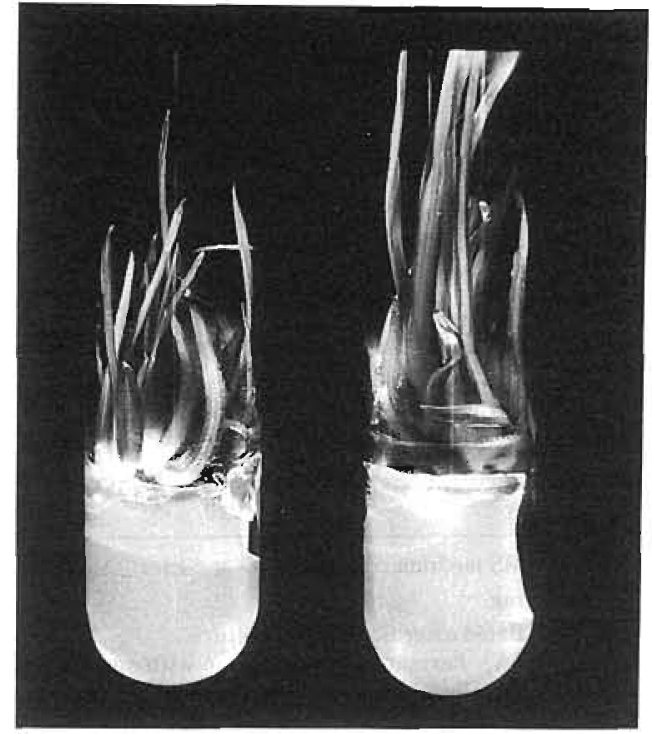

Fig. 3. Shoots formed directly on explants of perianth-ovary junction (A) with a filament from floral organs of Japanese iris 'Fujibakama' cultured on medium with $5 \mathrm{mg} \cdot$ liter $^{-1}$ each of BA and NAA.

Culture period : 64 days.

Table 1. In vitro morphogenic response of perianth-ovary junction and ovary explants from floral organs in Japanese iris, 'Fujibakama' cultured on MS media ${ }^{z}$ containing various concentrations of BA and NAA.

\begin{tabular}{|c|c|c|c|c|c|c|}
\hline \multirow{2}{*}{$\begin{array}{l}\text { Explant } \\
\text { organs }\end{array}$} & \multirow{2}{*}{$\begin{array}{l}\text { Plant growth } \\
\text { regulator } \\
\left(\text { mg }^{-} \text {liter }^{-1}\right) \\
(\mathrm{BA}-\mathrm{NAA})\end{array}$} & \multirow{2}{*}{$\begin{array}{l}\text { No. of } \\
\quad \text { cultures }\end{array}$} & \multicolumn{4}{|c|}{ Cultures $(\%)^{y}$} \\
\hline & & & Shooting & Rooting & $\begin{array}{l}\text { Forming } \\
\text { callus }\end{array}$ & $\begin{array}{l}\text { Turning } \\
\text { brown }\end{array}$ \\
\hline \multirow{3}{*}{$\begin{array}{l}\text { Perianth-ovary } \\
\text { junction }\end{array}$} & $5-5$ & 9 & 67 & 0 & 0 & 22 \\
\hline & $1-1$ & 9 & 100 & 0 & 0 & 0 \\
\hline & $0-0$ & 9 & 0 & 0 & 0 & 100 \\
\hline Upper & $5-5$ & 8 & 63 & 0 & 100 & 0 \\
\hline portion ${ }^{x}$ & $1-1$ & 8 & 50 & 13 & 100 & 0 \\
\hline Ovary & $0-0$ & 8 & 0 & 0 & 0 & 100 \\
\hline Lower & $5-5$ & 8 & 38 & 100 & 100 & 0 \\
\hline \multirow{2}{*}{ portion ${ }^{w}$} & $1-1$ & 8 & 0 & 100 & 100 & 0 \\
\hline & $0-0$ & 8 & 0 & 0 & 0 & 100 \\
\hline
\end{tabular}

$z$ MS medium containing $30 \mathrm{~g} \cdot$ liter $^{-1}$ sucrose and $10 \mathrm{~g} \cdot$ liter $^{-1}$ agar, pH adjusted to 5.8 prior to autoclav. ing.

y Rated after about 2 months in culture.

$x$ Upper portion; upper segment divided horizontaly into two parts, each of which was further divided verti. cally into two parts.

" Lower portion; lower segment divided horizontaly into two parts, each of which was further divided vertically into two parts. 
Table 2. In vitro morphogenic response of perianth-ovary junction and filament explants from floral organs of Japanese iris, 'Fujibakama' on MS media ${ }^{2}$ containing various concentrations of BA and NAA.

\begin{tabular}{|c|c|c|c|c|c|c|}
\hline \multirow{2}{*}{$\begin{array}{l}\text { Explant } \\
\text { organs }\end{array}$} & \multirow{2}{*}{$\begin{array}{l}\text { Plant growth } \\
\text { regulator } \\
\left(\mathrm{mg} \cdot \text { liter }^{-1}\right) \\
(\mathrm{BA}-\mathrm{NAA})\end{array}$} & \multirow{2}{*}{$\begin{array}{l}\text { No. of } \\
\text { cultures }\end{array}$} & \multicolumn{4}{|c|}{ Cultures $(\%)^{y}$} \\
\hline & & & Shooting & Rooting & $\begin{array}{l}\text { Forming } \\
\text { callus }\end{array}$ & $\begin{array}{l}\text { Turning } \\
\text { brown }\end{array}$ \\
\hline \multirow{4}{*}{$\begin{array}{l}\text { Perianth-ovary } \\
\text { junction }{ }^{x} \\
\text { (A) }\end{array}$} & $5-5$ & 6 & 100 & 0 & 0 & 0 \\
\hline & $5-1$ & 7 & 57 & 0 & 0 & 0 \\
\hline & $1-1$ & 7 & 86 & 0 & 0 & 0 \\
\hline & $0-0$ & 3 & 0 & 0 & 0 & 100 \\
\hline \multirow{4}{*}{$\begin{array}{l}\text { Perianth-ovary } \\
\text { junction }{ }^{w} \\
\text { (B) }\end{array}$} & $5-5$ & 2 & 100 & 0 & 0 & 0 \\
\hline & $5-1$ & 2 & 50 & 0 & 0 & 0 \\
\hline & $1-1$ & 2 & 50 & 0 & 0 & 0 \\
\hline & $0-0$ & 2 & 0 & 0 & 0 & 100 \\
\hline \multirow[t]{4}{*}{ Filament } & $5-5$ & 2 & 0 & 0 & 0 & 0 \\
\hline & $5-1$ & 2 & 0 & 0 & 0 & 0 \\
\hline & $1-1$ & 3 & 0 & 0 & 0 & 0 \\
\hline & $0-0$ & 2 & 0 & 0 & 0 & 100 \\
\hline \multicolumn{7}{|c|}{$\begin{array}{l}\text { MS medium containing } 30 \mathrm{~g} \cdot \text { liter }^{-1} \text { sucrose and } 10 \mathrm{~g} \cdot \text { liter }^{-1} \text { agar, } \mathrm{pH} \text { adjusted to } 5.8 \text { prior to autoclav } \\
\text { ing. }\end{array}$} \\
\hline \multicolumn{7}{|c|}{$\begin{array}{l}\text { yated after } 63 \text { days in culture. } \\
x \text { (A): Perianth-ovary junction with one filament. } \\
\text { w (B): Perianth-ovary junction without filament. }\end{array}$} \\
\hline
\end{tabular}

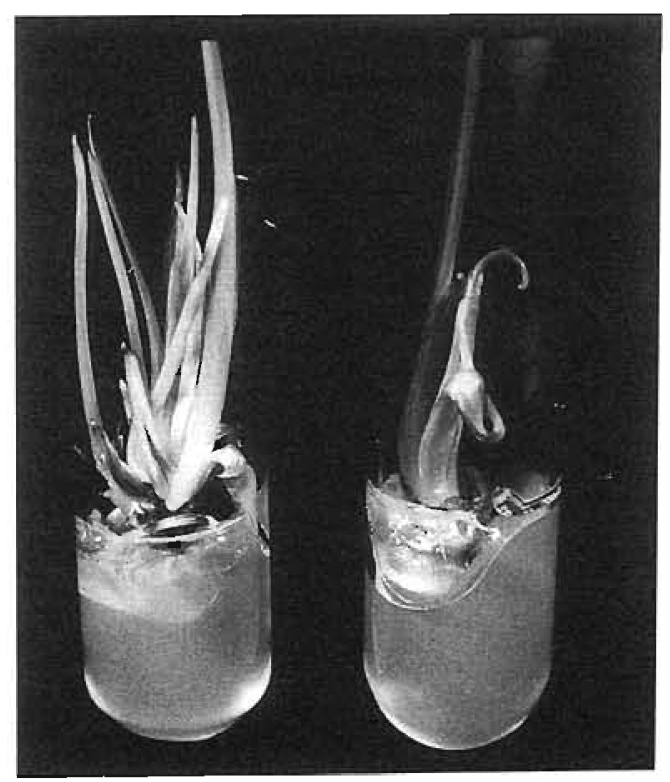

Fig. 4. Shoots formed directly on explants of perianth-ovary junction (B) without a filament from floral organs of Japanese iris 'Fujibakama' cultured on medium with $5 \mathrm{mg} \cdot \mathrm{liter}^{-1}$ each of BA and NAA.

Culture period : 64 days. obtained at a high frequency on media with BA and NAA. Lower portions formed shoots only on a medium with $5 \mathrm{mg} \cdot$ liter $^{-1}$ each of BA and NAA, but at a low frequency.

\section{Root formation}

Even after about 2 months of culture, no root formation was observed from explants of perianthovary junctions, pistils, perianths, stamens, anthers and filaments on media with or without $\mathrm{BA}$ and NAA.

In the case of ovaries, no explants formed roots on the medium without BA and NAA, but most explants of lower portions formed roots on media with BA and NAA. Explants of upper portions did not exhibit root forming ability on media with $B A$ and NAA, although one explant formed roots on a medium with $1 \mathrm{mg} \cdot$ liter $^{-1}$ each of BA and NAA.

In general, pedicels showed no root formation ability, except for only one of three explants on the medium without BA and NAA.

\section{Callus formation}

Explants of perianth-ovary junctions, pistils, perianths, anthers, filaments and pedicels never formed callus on any media.

In contrast, every kind of explant from ovaries showed a high capacity for callus formation on 
media with BA and NAA.

Stamen explants formed callus at a frequency of 11 percent on a medium with $5 \mathrm{mg} \cdot \operatorname{liter}^{-1}$ each of $\mathrm{BA}$ and $\mathrm{NAA}$

\section{Discussion}

Explants taken from rhizomes had previously been found to be frequently contaminated on culture media (Ichihashi and Kato, 1986; Kawase, unpublised manuscript), but the present study showed that various explants from floral organs of Japanese iris were obtained almost entirely free from contamination.

The results of floral organ culture have shown that shoot regeneration can be achieved at a high percentage by perianth-ovary junctions, as was shown in the case of Siberian iris (Asao et al., 1993), and upper portions of ovaries, but no shoot regeneration by pistils, stamens, anthers, filaments, perianths and pedicels was observed.

The regeneration of shoots on perianth-ovary junctions and ovaries occurred directly without intervening callus formation on explant tissues, as in the case of ovary explants in some species of Liliaceae and Amarylidaceae (Hussey, 1975) and ovary or sepal explants of Omithogalum thyrsoides (Hussey, 1976).

On the culture of perianth-ovary junctions, small protuberances appeared near a filament of the explants after one month in culture, and they increased in number and developed into a mass of multiple shoots about two months after culture. Explants from ovaries formed shoots on the apical cut end (upper side).

The additon of NAA and kinetin or BA is required for shoot formation from perianth bases or receptacle-ovary junctions on Siberian iris (Asao et al., 1993; Meyer, 1984), peduncles on tall bearded irises (Meyer et al., 1975) and ovaries or scapes on Japanese iris (Ichihashi and Kato, 1986; Yabuya et al., 1991). We may conclude that shoot formation on perianth-ovary junctions and ovaries was strongly affected by the presence of $B A$ and NAA in the medium. Even at low levels of BA and NAA, explants of perianth-ovary junctions showed a very high percentage of shoot formation, but no shoot formation occurred without BA and NAA. Shoot formation at low levels of the plant growth regulators is a good way to avoid mutation caused by high concentrations of them (Niizeki, 1974).
From the fact that perianth-ovary junctions from 'Fujibakama' formed shoots at a high frequency, it appears that shoots may be regenerated from the tissues of other cultivars of Japanese iris.

Ziv et al. (1973) reported that root primordia from inflorescence stem explants of Alstroemeria could be formed at a wide range of NAA and kinetin combinations. Bentz et al. (1988) reported that NAA was not required and BA was clearly inhibitory to rooting of shoot tip explants from Yucca glauca. The present study showed that ovary explants required $\mathrm{BA}$ and NAA for root formation, but high concentrations of both BA and NAA inhi. bited the rooting of upper portions of ovary explants. The roots regenerated directly on the basal cut end of the ovary. In the case of ovaries, the frequency of shoot formation was higher on upper portions than on lower portions, but root formation was higher on the lower than on the upper portion.

Ichihashi and Kato (1986) reported that BA was not essential for the formation of callus on ovary explants of Japanese iris, however, that it did promote the growth of callus. Meyer et al. (1975) indicated that the best callus growth occurred at $2.5 \mathrm{mg} \cdot$ liter $^{-1} \mathrm{NAA}$ and $0.5 \mathrm{mg} \cdot$ liter $^{-1}$ kinetin. In the present study, callus formation was only noticed on explants of ovaries and stamens. All ovary explants showed callus formation on media with BA and NAA. Moreover, ovaries seem to be a useful source of mutants, if their callus can easily form shoots.

Our study shows that perianth-ovary junctions and ovaries are tissues suitable for shoot organogenesis, i.e., for micropropagation. However, shoot yield from perianth-ovary junctions and ovaries in this study was relatively low and sufficient root formation was not obtained. Currently, we are attempting to obtain shoot multiplication and root induction by the use of different strengths of MS medium and various combinations of plant growth regulators.

Floral organ culture has several advantages over current propagation methods; namely, that explants cause little contamination in in vitro culture; numerous explants are obtained from a single flower stalk with 4 to 5 flowers; perianth-ovary junctions have a high capacity for forming shoots; and finally, this method causes no damage to the mother plants. 


\section{Acknowledgements}

The authors are grateful to Professor Dr. H. Yukinaga, Kyoto University, for his valuable suggestions and to Dr. Yoshihiro Sakanishi for his critical reading of this manuscript.

\section{Literature Cited}

Asao, T., K. Kawase and M. Yoshioka. 1993. In vitro shoot formation from explants of perianth base and ovary in Siberian irises. Plant Tissue Cult. Lett. $10: 188-190$. (In Japanese).

Bentz, S. E., B. J. Parliman, H. J. Talbott and W. L. Ackerman. 1988. Factors affecting in vitro propagation of Yucca glauca. Plant Cell Tissue and Organ Culture 14:111-120.

Heuser, C. and D. A. Apps. 1976. In vitro plantlet formation from flower petal explants of Hemerocallis cv. Chipper Cherry. Can. J. Bot. 54:616-618.

Hussey, G. 1975. Totipotency in tissue explants and callus of some members of the Liliaceae, Iridaceae and Amaryllidaceae. J. Exp. Bot. $26: 253-262$.

Hussey, G. 1976. Plantlet regeneration from callus and parent tissue in Ornithogalum thyrsoides. J. Ext. Bot. 27 : 375-382.

Ichihashi, S. and S. Kato. 1986. Clonal propagation of
Iris kempferi by means of flower organ culture. Bull. Aichi Univ. Education. 35 : 135-143.

Iizuka, M., S. Hla-bo and R. Madrigal. 1978. Floral organ culture and organogenesis of cruciferous plants. Japan J. Breed. 28: 151-158.

Kohlein, F. 1987. Iris. Christopher Helm, London.

Meyer, M. M. Jr. 1984. In vitro propagation of Siberian iris from flower stalks. HortScience $19: 575$. (Abstr.).

Meyer, M. M. Jr., L. H. Fuchigami and A. N. Roberts. 1975. Propagation of tall bearded irises by tissue culture. HortScience $10: 479-480$.

Montezuma-de-Caryalho, J. and M. L. L. Guimaraes. 1974. Production of buds and plantlets from the stamen's filament of Lilium regale cultivated in vitro. Biol. Plant. 16:472-473.

Niizeki, M. 1974. Studies on plant cell and tissue culture. V. Effect of different kinds of media on the variation of chromosome numbers in tobacco callus and regenerated plant. J. Fac. Agri., Hokkaido Univ. $57: 357-367$.

Yabuya, T., Y. Ikeda and T. Adachi. 1991. In vitro propagation of Japanese garden iris, Iris ensata Thunb. Euphytica $57: 77-81$.

Ziv, M., R. Kanterovitz and A. H. Halevy. 1973. Vegetative propagation of Alstroemeria in vitro. Scientia Hortic. 1 : 271-277.

\title{
ハナショウブの培養された花器における苗条形成
}

\author{
河瀬晃四郎 - 水谷 博* ·吉岡麻理 - 福田園子 \\ 京都大学宸学部附属農場 569 高規市八丁㪞町 12-1
}

\begin{abstract}
摘
ハナショウブの增殖を目的に，雌ずい，花被，雄ず い, 葯, 花系, 花被・子房接合部(花被と子房が接合 した部分)，子房扔よび小花梗を外植体とし，BA およ びNAA を添加したMS 培地でそれらの培養を行った。

苗条形成は花被と子房の接合部切片扔上び子房切片 で認められたが，これらを除く他の切片における苗条 形成は認められなかった。これらの切片における苗条 形成は, BA およびNAA 添加培地でのみ認められ, 特に子房の下部切片の場合は，BA おょびNAAの 5 $\mathrm{mg} \cdot \mathrm{liter}^{-1}$ 添加培地で培荄した場合にのみ苗条の形状 が認められた，花被と子房の接合部切片に㧍ける苗条 形成率は子房切片上りも高かった。
\end{abstract}

要

根の形成は子房および小花梗を除いた他の外植体で は認められなかった，子房の下部切片の場合，BAお よびNAA を添加した培地では，すべての外植体で発 根が認められたが，上部切片は $1 \mathrm{mg} \cdot \mathrm{m}_{\mathrm{S}}$ ler ${ }^{-1}$ の濃度で $\mathrm{BA}$ およびNAA を添加した培地でのみ発根した。 小 花梗では BA およびNAAの無添加培地においてのみ 根の形成が認められ，その形成率は $33 \%$ であった。

カルス形成は子房抢よび雄ずいで認められた，BA およびNAAの両者を添加した培地では，すべての子 房切片でカルス形成が認められた。雄ずいは BA 扔よ びNAAの $5 \mathrm{mg} \cdot$ liter $^{-1}$ 添加培地でのみカルスを形成

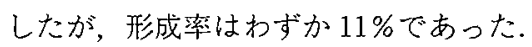

\footnotetext{
*現在：滋賀県立長浜農湴高等学校
} 